\title{
PERAN EMOSI POSITIF MEMEDIASI PENGARUH FASHION INVOLVEMENT DAN HEDONIC CONSUMPTION TENDENCY TERHADAP IMPULSE BUYING
}

\author{
Ida Ayu Diksita Kinasih ${ }^{1}$ \\ I Made Jatra ${ }^{2}$ \\ ${ }^{1,2}$ Fakultas Ekonomi dan Bisnis Universitas Udayana, Bali, Indonesia \\ email: iadiksitakinasih@gmail.com
}

\begin{abstract}
ABSTRAK
Tujuan penelitian ini adalah untuk menguji pengaruh fashion involvement dan hedonic consumption tendency terhadap emosi positif, pengaruh fashion involvement, hedonic consumption tendency dan emosi positif terhadap impulse buying, dan peran emosi positif memediasi pengaruh fashion involvement dan hedonic consumption tendency terhadap impulse buying pada pelanggan produk fashion Discovery Shopping Mall Kuta. Metode yang digunakan untuk menentukan sampel adalah non-probability berbentuk purposive sampling dengan ukuran sampel sebanyak 105 orang responden. Pengumpulan data dilakukan dengan penyebaran kuesioner secara langsung pada pelanggan produk fashion Discovery Shopping Mall Kuta. Teknik analisis yang digunakan adalah analisis jalur (path analysis) dan uji sobel. Terdapat hubungan yang positif dan signifikan antara fashion involvement dan hedonic consumption tendency terhadap emosi positif, hubungan yang positif dan signifikan antara fashion involvement, hedonic consumption tendency dan emosi positif terhadap impulse buying. Emosi positif dapat berperan sebagai variabel mediasi yang signifikan antara pengaruh fashion involvement dan hedonic consumption tendency terhadap impulse buying.
\end{abstract}

Kata kunci: fashion involvement, hedonic consumption tendency, emosi positif, dan impulse buying.

\begin{abstract}
The purpose of this study was to examine the effect of fashion involvement and hedonic consumption tendency on positive emotions, the influence of fashion involvement, hedonic consumption tendency and positive emotion on impulse buying, and the role of positive emotions mediate the influence of fashion involvement and hedonic consumption tendency toward impulse buying on fashion products Discovery Shopping Mall Kuta. The method used to determine the sample is non-probability in the form of purposive sampling with sample size of 105 respondents. Data collection was done by distributing questionnaires directly to customers of fashion products Discovery Shopping Mall Kuta. The analysis technique used is path analysis and sobel test. There is a positive and significant relationship between fashion involvement and hedonic consumption tendency toward positive emotion, positive and significant relationship between fashion involvement, hedonic consumption tendency and positive emotion toward impulse buying. Positive emotions can act as significant mediation variables between the influence of fashion involvement and hedonic consumption tendency toward impulse buying.
\end{abstract}

Keywords: fashion involvement, hedonic consumption tendency, positive emotions, and impulse buying buying 


\section{PENDAHULUAN}

Perkembangan jaman yang semakin modern saat ini ditandai dengan pesatnya pendirian bisnis ritel modern di Indonesia. Beberapa contoh bentuk bisnis ritel modern di Indonesia adalah minimarket, supermarket, department store, mall dan lainnya yang tersebar di seluruh wilayah di Indonesia. Menurut marketing.co.id gerai ritel di Indonesia tiap tahunnya mengalami pertumbuhan rata-rata 17,57 persen dalam kurun waktu 2007-2012. Usaha ritel di Indonesia Tahun 2007 tercatat berjumlah 10.365 gerai kemudian meningkat mencapai 18.152 gerai pada Tahun 2011 yang tersebar di masing-masing kota seluruh Indonesia.

Perkembangan bisnis ritel di Indonesia dapat dikatakan menjadi sebuah faktor yang mendorong berkembangnya trend fashion di Indonesia. Dilihat dari banyaknya permintaan di pasar akan trend fashion yang sedang berkembang serta mendominasinya gerai fashion yang terdapat dalam bisnis ritel seperti mall juga menunjukkan perkembangan fashion kian meningkat di Indonesia. Japarianto dan Sugiharto (2011) menyatakan bahwa fashion adalah produk utama dari sebuah mall atau shopping centre. Di Bali hampir semua mall menjual berbagai kebutuhan fashion, seperti Discovery Shopping Mall Kuta, Mall Bali Galeria, Beachwalk, Matahari Department Store dan lainnya. Sebagian besar gerai yang ada di mall-mall tersebut merupakan gerai yang menawarkan produk fashion. Kemunculan brand-brand ternama dunia di mall Bali seperti Sogo, Hush Puppies, Zara, Bershka, HnM, Pull and Bear, Stradivarius dan lainnya dapat mengindikasikan bahwa fashion di Bali saat ini semakin berkembang. 
Seiring perkembangan trend fashion yang sangat dinamis serta kemunculan brand fashion ternama di masing-masing mall di Bali menuntut pelaku bisnis fashion untuk cepat mengikuti trend fashion yang ada ataupun menciptakan trend fashion terbaru, sehingga akan dapat menimbulkan perilaku pembelian konsumen baik yang direncanakan sebelumnya maupun yang tidak terencana (impulse buying). Impulse buying dikatakan sebagai suatu desakan hati secara tiba-tiba dengan penuh kekuatan, bertahan, dan tidak direncanakan untuk membeli sesuatu secara langsung, tanpa banyak memperhatikan akibatnya (Rachmawati, 2009). Impulse buying dikenal sebagai pembelian tidak terencana dengan pengambilan keputusan yang cepat (Dhurup, 2014). Japarianto dan Sugiharto (2011) menyatakan impulse buying merupakan pembelian yang tidak direncanakan akibat adanya rangsangan dari lingkungan belanja. Gautierrez (2004) menyatakan tidak semua produk dapat menimbulkan impulse buying melainkan beberapa produk yakni pakaian, parfum, make-up, stationery, dan lainnya.

Masyarakat Indonesia menjadi semakin impulsif saat berbelanja ditunjukkan dari beberapa indikasi menurut survei yang dilakukan oleh AC Nielsen pada bulan Juni 2013 kepada 1. 804 responden di sejumlah kota besar di Indonesia. Hasil survei menunjukkan tren pembelian impulsif masyarakat Indonesia cenderung mengalami kenaikan setiap tahunnya. Dari tahun 2005 hingga 2013 masyarakat cenderung menjadi pembeli impulsif yang terlihat dari beberapa indikasi yang menunjukkan kenaikan, seperti: indikasi masyarakat tidak merencanakan apa yang akan dibeli dan pernah membeli barang-barang tambahan yang tidak direncanakan mengalami kenaikan 10 persen; indikasi tidak pernah merencanakan apa yang 
akan mereka beli sebelum berbelanja mengalami kenaikan 11 persen; indikasi selalu membeli barang tambahan meskipun telah merencanakan apa saja yang akan dibeli mengalami peningkatan sebanyak 26 persen; indikasi selalu membeli barang tambahan saat berbelanja mengalami kenaikan tertinggi sebesar 30 persen; dan indikasi mengunjungi toko yang memberikan penawaran menarik dan kupon promosi yang koran atau flyers sebesar 16 persen.

Impulse buying dapat terjadi ketika seseorang memiliki keterlibatan fashion yang didasarkan pada kecenderungan mengikuti trend fashion. Keterlibatan adalah sebuah keadaan dorongan dari gairah atau kepentingan yang ditimbulkan dari stimuli atau situasi, dan display atau penampilan melalui properti (O’Cass: 2004). Keterlibatan fashion (fashion involvement) merupakan tingkat keterlibatan individu terhadap produk fashion yang berkaitan dengan trend pakaian terbaru (Pattipeilohy et al. 2013). Keaadan konsumen memiliki keterlibatan tinggi terhadap fashion berkemungkinan besar dalam membeli sebuah produk fashion dalam skala pembelian impulsif (Park et al. 2006). Hal serupa juga diungkapkan oleh Marianty (2014) yang menyatakan bahwa konsumen yang memiliki keterlibatan fashion yang tinggi memungkinkan melakukan pembelian secara impulsif pada produk-produk fashion. Tingkat keterlibatan konsumen yang tinggi pada sebuah produk pakian akan memiliki perbedaan dengan konsumen yang tidak terlibat (Hourigan and Bougoure, 2012). Hal ini menunjukkan bahwa keputusan pembelian oleh konsumen dapat dipengaruhi dengan keterlibatan konsumen. Khare and Rakesh (2010) menyebutkan bahwa tingkat keterlibatan 
yang tinggi oleh konsumen akan fashion memiliki pengaruh yang lebih tinggi terhadap keputusan pembelian.

Faktor penting lainnya yang dapat memprediksi timbulnya impulse buying adalah hedonic consumption tendency (Liapati, 2015). Menurut Hoch \& Loewenstein (1991) konsumsi hedonis secara umum dapat disebut sebagai ciri-ciri individu untuk terlibat dalam kegiatan yang menghasilkan kesenangan. Menurut Saleem et al. (2012) juga menyatakan kegiatan individu yang menghasilkan kesenangan merupakan suatu sifat kecenderungan individu mengkonsumsi secara hedonis. Impulse buying seringkali melibatkan komponen hedonik atau afektif menurut Cob and Hoyer (dalam Rohman 2012:33). Dananjaya dan Suparna (2016) menyatakan terdapat hubungan antara impulse buying dan motivasi belanja hedonis, secara tidak langsung ketika konsumen melakukan impulse buying pada saat itu juga konsumsi hedonis dapat dipenuhi. Konsumen dianjurkan untuk melakukan impulse buying untuk memenuhi kebutuhan hedonis atau untuk alasan non-ekonomi, seperti pergi untuk kesenangan serta kepuasan sosial dan emosional individu (Hausman, 2000). Peristiwa pembelian impulsif dapat terjadi ketika seseorang menganggap tujuan belanja adalah sebagai pemenuhan kebutuhan hedonis, nampaknya pembelian produk dilakukan tanpa ada perecanaan sebelumnya (Marianty, 2014)

Emosi positif merupakan salah satu komponen proses afektif dari proses psikologis dalam pembelian impulsif. Emosi positif dikatakan sebagai suatu keadaan dimana (calon) konsumen memiliki suasana hati positif yang berasal dari motivasinya untuk memuaskan diri melalui pembelian impulsif (Coley dalam 
Mulyono, 2012). Verplanken (dalam Muruganantham \& Bhakat, 2013) mengatakan bahwa, pengalaman pembelian pada konsumen impulsif didasarkan pada emosi yang tinggi. Umumnya, emosi positif dalam waktu pembelian dapat menyebabkan meningkatnya pelanggan pembelian impulsif dan memainkan peran penting dalam niat mereka untuk melakukan pembelian (Chaudhuri dan Holbrook, 2002).Emosi positif merupakan suatu perasaan senang atau gembira yang dipengaruhi oleh berbagai lingkungan, yang dapat mendorong terjadinya pembelian impulsif saat sedang berbelanja. Amiri et al. (2012) menyatakan bahwa meningkatnya motivasi untuk melakukan pembelian impulsif dapat terjadi ketika terbentuknya emosi positif pelanggan terhadap produk atau lingkungan toko.

Park et al. (2006) dalam penelitiannya menyebutkan tidak ada pengaruh hedonic consumption tendency terhadap impulse buying, namun ditemukan bahwa ada pengaruh tidak langsung untuk hedonic consumption tendency terhadap pembelian impulsif melalui emosi positif sebagai varaibel mediasi yang signifikan. Selain itu, dalam penelitian Permatasari dkk. (2017) menyatakan bahwa secara tidak langsung hedonic consumption tendency melalui emosi positif juga berpengaruh terhadap pembelian impulsif. Penelitian Willy dan Warmika (2015) menyatakan bahwa keterlibatan akan fashion yang tinggi akan menunjukkan emosi yang lebih positif dan dapat meningkatkan impulse buying. Amiri et al. (2012) menyatakan pelanggan memiliki fashion involvement yang tinggi menunjukkan emosi positif yang lebih tinggi dan dapat meningkatkan pembelian impulsif. Berdasarkan beberapa hasil penelitian tersebut emosi positif 
dapat menjadi variabel mediasi yang signifikan antara fashion involvement dan hedonic consumption tendency terhadap impulse buying.

Salah satu pusat ritel modern yang berada di Bali adalah Discovery Shopping Mall Kuta. Discovery Shopping Mall Kuta terletak di Kabupaten Badung. Discovery Shopping Mall Kuta merupakan mal modern dan memiliki fasilitas lengkap sehingga dapat menarik minat konsumen untuk berkunjung. Berdasarkan survei awal yang dilakukan oleh peneliti terhadap 30 orang responden, 19 orang diantaranya memilih Discovery Shopping Mall Kuta sebagai lokasi untuk berbelanja produk fashion. Dari 19 orang tersebut diperoleh hasil bahwa $63 \%$ responden pernah melakukan impulse buying yang berorientasi produk fashion di Discovery Shopping Mall Kuta.

Penelitian ini dilakukan yang didasarkan pada beberapa temuan dari penelitian sebelumnya tentang pengaruh fashion involvement, hedonic consumption tendency dan emosi positif terhadap impulse buying dengan hasil yang berbeda-beda. Dalam penelitiannya Dhurup (2014) ditemukan bahwa tidak ada hubungan yang signifikan antara motivasi hedonik terhadap impulse buying. Hal serupa juga terdapat pada hasil penelitian Park et al. (2006) menyatakan bahwa tidak ada pengaruh pada hedonic consumption tendency terhadap impulse buying, namun ditemukan bahwa adanya pengaruh tidak langsung untuk hedonic consumption tendency pada impulse buying melalui emosi positif sebagai variabel mediasi yang signifikan. Hal ini sejalan dengan hasil penelitian Vazifehdoost et al. (2014) yang menemukan bahwa hedonic consumption tendency memiliki pengaruh tidak langsung terhadap impulse buying melalui emosi positif. Hasil ini 
bertolak belakang dengan penelitian Permatasi dkk. (2017) yang menyatakan bahwa hedonic consumption tendency memiliki pengaruh signifikan terhadap impulse buying.

Hasil penelitian Willy \& Warmika (2015) menemukan bahwa fashion involvement berpengaruh positif dan signifikan terhadap emosi positif hal ini bertolak belakang dengan hasil penelitian yang dilakukan oleh Riana dkk. (2015) yang menyatakan bahwa fashion involvement berpengaruh negatif dan tidak signifikan terhadap emosi positif.

Hasil dari penelitian Willy \& Warmika (2015) mengatakan emosi positif secara positif memediasi pengaruh fashion involvement terhadap pembelian impulsif. Hal ini tidak sejalan dengan temuan dari penelitian Riana dkk. (2015) menyatakan adanya pemgaruh negatif namun tidak signifikan antara fashion involvement secara tidak langsung terhadap impulse buying melalui mediator emosi positif.

Tingkat fashion involvement yang tinggi menyebabkan konsumen lebih memungkinkan untuk mengalami emosi positif misalnya merasa bersemangat dan puas selama berbelanja (Park et al. 2006). Penelitian Park et al. (2006) menyatakan bahwa fashion involvement dapat meningkatkan pengalaman emosi ketika berbelanja. Pattipeilohy et al. (2013) keterlibatan fashion yang dialami konsumen akan dapat menyebabkan meningkatnya emosi positif karena konsumen merasa puas dan senang terhadap kualitas produk fashion yang ditawarkan atau dijual. Hasil penelitian yang dilakukan oleh Amiri et al. (2012) sejalan dengan hasil penelitian Park et al. (2006) menunjukkan bahwa fashion 
involvement berpengaruh secara positif terhadap emosi positif dalam waktu pembelian. Penelitian yang dilakukan oleh Willy \& Warmika (2015) juga Pattipeilohy et al. (2013) menemukan bahwa fashion involvement berpengaruh positif dan signifikan terhadap emosi positif.

$\mathrm{H}_{1}$ : Fashion involvement berpengaruh positif dan signifikan terhadap emosi positif.

Hedonic consumption tendency secara signifikan dan positif berhubungan langsung dengan emosi positif dalam Park et al. (2006), dimana konsumen akan merasa lebihh bersemangat, puas dan senang ketika sedang berbelanja, ketika konsumen menunjukkan keingintahuannya, adanya keinginan konsumen terhadap pengalaman batru ketika berbelanja. Semakin meningkatnya hedonic consumption tendency menyebabkan juga semakin meningkatnya emosi positif konsumen saat melakukan kegiatan belanja (Pattipeilohy et al. 2013). Penelitian sebelumnya oleh Bloch et al. (1991) dan Roy (1994) dalam Permatasari dkk. (2017) terdapat temuan yang menggambarkan peningkatan motivasi dalam memuaskan emosi seperti rasa bahagia melibatkan sifat hedonic. Emosi positif dapat diciptakan oleh hedonic consumption tendency yang tingi pada konsumen ketika berbelanja produk fashion. Hal ini disebabkan karena konsumen mendapat pengalaman berbelanja yaitu konsumen merasa betah dan nyaman terhadap lingkungan tersebut (Permatasari dkk. 2017). Hasil penelitian Permatasari dkk. (2017) sejalan dengan hasil penelitian Marianty (2014) yang menunjukkan bahwa pengaruh hedonic consumption tendency terhadap emosi positif adalah positif dan 
signifikan. Penelitian Riana dkk. (2015) menyatakan bahwa hedonic consumption tendency juga berpengaruh positif dan signifikan terhadap emosi positif.

$\mathrm{H}_{2}$ : Hedonic consumption tendency berpengaruh positif dan signifikan terhadap emosi positif.

Dalam penelitian yang dilakukan Amiri (2012) dan Vazifehdoost (2014) menghasilkan bahwa fashion involvement berpengaruh positif terhadap impulse buying. Hasil penelitian yang dilakukan oleh Park et al. (2006) menyatakan bahwa fashion involvement memiliki pengaruh positif signifikan terhadap impulse buying behavior. Penelitiaan yang dilakukan oleh Willy \& Warmika (2015), Dananjaya \& Suparna (2016), Japarianto dan Sugiharto (2011) menghasilkan temuan bahwa terdapat pengaruh positif dan signifikan antara fashion involvement terhadap impulse buying.

$\mathrm{H}_{3}$ : Fashion involvement berpengaruh positif dan signifikan terhadap impulse buying.

Hasrat hedonis seperti kesenangan, menemukan dan merasakan hal-hal yang baru, fantasi, interaksi sosial dan emosional dapat menentukan perilaku pembelian impulsif (Park et al. 2006). Hedonic consumption tendency berpengaruh secara positif signifikan terhadap impulse buying dalam Permatasari dkk. (2017). Amiri (2012) dalam penelitiannya menyatakan bahwa hedonic consumption tendency memiliki pengaruh positif terhadap impulse buying, dengan kata lain pelanggan dengan hedonic consumption tendency tinggi menunjukkan kecenderungan lebih untuk pembelian impulsif. Hasil penelitian dari Marianty (2014) dan Riana dkk. 
(2015) menyatakan bahwa kecenderungan konsumsi hedonik berpengaruh positif dan signifikan terhadap pembelian impulsif.

$\mathrm{H}_{4}$ : Hedonic consumption tendency berpengaruh positif dan signifikan terhadap impulse buying.

Menurut Beatty and Farrel dalam Riana dkk. (2015) kedekatan fisik dengan objek selama pencarian di pusat perbelanjaan merupakan dorongan atau keinginan untuk melakukan pembelian, pengalaman positif ketika berbelanja cenderung mendorong terjadinya pembelian impulsif. Amiri (2012) menyatakan bahwa umumnya emosi yang semakin positif dalam waktu pembelian dapat menyebabkan meningkatnya pembelian secara impulsif, emosi positif memainkan peran penting dalam niat mereka untuk membeli. Amiri (2012) dalam hasil penelitiannya menyatakan bahwa emosi positif memiliki pengaruh positif terhadap impulse buying. Dalam penelitian yang dilakukan oleh Permatasari dkk. (2017) menyatakan kondisi emosi seorang konsumen dapat berperan penting dalam pengambilan keputusan pembelian secara impulsif. Hasil penelitian Permatasari dkk. (2017) dan Naentiana \& Setiawan (2014) menunjukkan bahwa terdapat pengaruh positif dan signifikan antara emosi positif terhadap impulse buying.

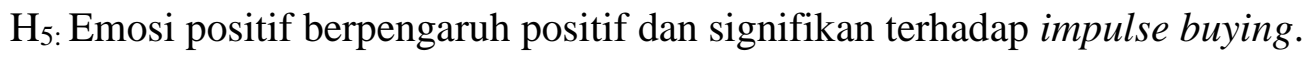

Berdasarkan penelitian oleh Nooreini (2014) memperoleh hasil bahwa fashion involvement memiliki pengaruh positif langsung dengan impulse buying baik secara tidak langsung melalui emosi positif. Saat sedang berbelanja emosi lebih positif oleh pelanggan muncul ketika mereka memiliki keterlibatan fashion 
yang tinggi, hal tersebut menunjukkan emosi yang positif saat berbelanja dapat menyebabkan meningkatnya keterlibatan dalam pembelian secara tidak terencana (Amiri, 2012). Willy dan Warmika (2015) dalam hasil penelitiannya menemukan bahwa fashion involvement mampu memediasi pengaruh positif dan signifikan positive emotion terhadap impulse buying konsumen fashion.

$\mathrm{H}_{6:}$ Emosi positif memediasi pengaruh fashion involvement terhadap perilaku impulse buying.

Marianty (2014) dalam penelitiannya menyatakan bahwa perilaku pembelian impulsif di dalam pusat perbelanjaan berasal dari motivasi belanja untuk memuaskan keinginan seperti pengalaman emosional yang didiorong kecenderungan konsumsi secara hedonis. Park et al. (2006) dalam penelitiannya menyatakan bahwa secara tidak langsung hedonic consumption tendency berpengaruh signifikan terhadap impulse buying melalui emosi positif sebagai variabel mediasi. Dalam penelitian yang dilakukan oleh Permatasari dkk. (2017) menunjukkan variabel hedonic consumption secara tidak langsung mempengaruhi pembelian impulsif melalui variabel emosi positif. Riana dkk (2015) dalam penelitiannya juga menyatakan hedonic consumption tendency secara tidak langsung mempengaruhi pembelian impulsif melalui variabel emosi positif yang berorientasi pada fashion.

$\mathrm{H}_{7}$ : Emosi positif memediasi pengaruh hedonic consumption tendency terhadap perilaku impulse buying. 


\section{Gambar 1. Kerangka Konseptual}

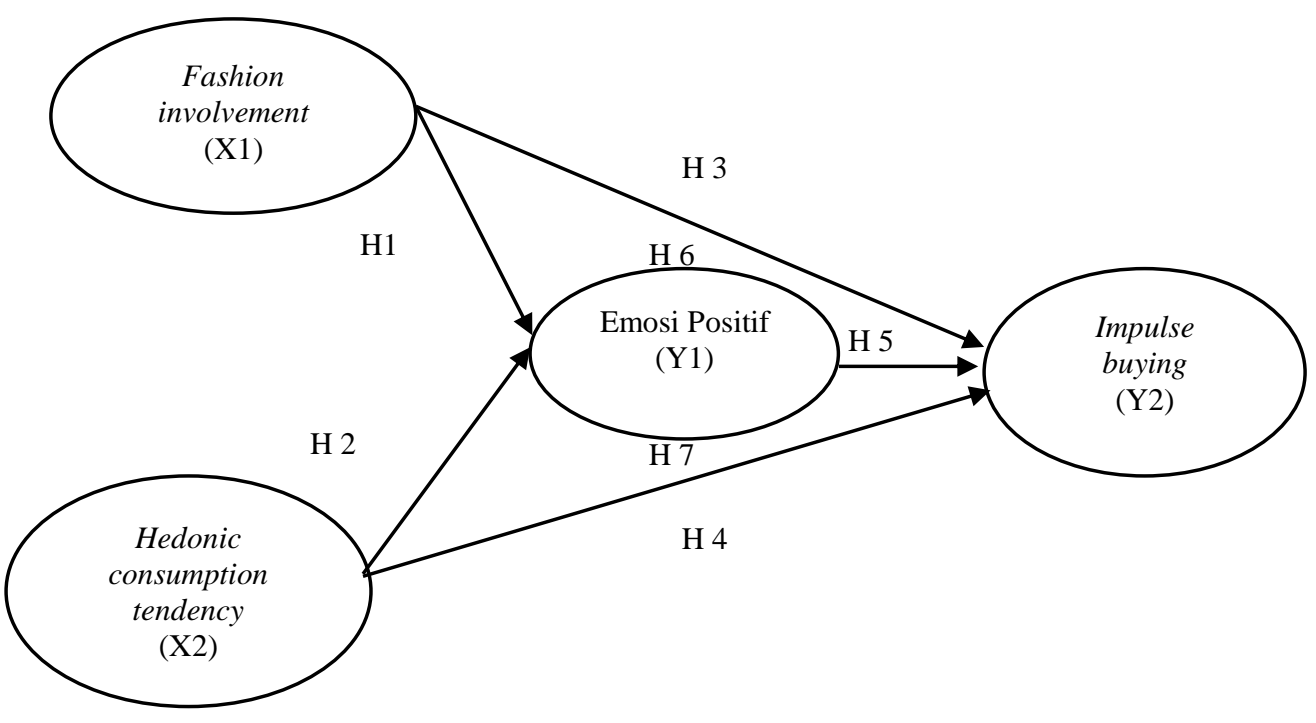

\section{METODE PENELITIAN}

Berdasarkan permasalahan yang diteliti, penelitian ini digolongkan pada penelitian asosiatif (hubungan), yaitu penelitian yang bertujuan untuk mengetahui hubungan dari dua variabel atau lebih (Sugiyono, 2017 :5) dengan menggunakan pendekatan kuantitatif. Penelitian ini mengambil tempat disalah satu mall yang berada di Kabupaten Badung, yakni Discovery Shopping Mall Kuta. Mall ini dipilih karena merupakan mall besar di Bali dengan fasilitas lengkap. Selain tidak berjauhan dengan tempat rekreasi pantai, Discovery Shopping Mall Kuta juga menyediakan berbagai macam kebutuhan masyarakat salah satunya kebutuhan fashion, dimana produk fashion yang ditawarkan di Discovery Shopping Mall Kuta merupakan produk fashion terbaru (up to date), sehingga kecenderungan untuk melakukan impulse buying akan lebih besar.

Populasi dalam penelitian ini adalah pelanggan yang pernah melakukan pembelian produk fashion di Discovery Shopping Mall Kuta dengan jumlah 
populasi yang tidak diketahui secara pasti (infinite). Sampel yang digunakan dalam penelitian ini berjumlah 105 responden. Metode penentuan sampel yang digunakan dalam penelitan ini adalah non probability sampling. Teknik pengambilan sampel ditentukan dengan metode purposive sampling merupakan metode pemilihan sampel berdasarkan pertimbangan tertentu (Sugiyono, 2017: 85). Metode pengumpulan data dalam penelitian menggunakan kuesioner.

Jenis data yang digunakan dalam penelitian ini dapat dibedakan menjadi dua, yaitu data kualitatif dan data kuantitatif. Dalam penelitian ini data kualitatif seperti gambaran umum tentang pelanggan produk fashion Discovery Shopping Mall Kuta, gambaran umum mengenai Discovery Shopping Mall Kuta dan persepsi responden terhadap pernyataan-pernyataan yang diajukan dalam kuesioner. Data Kuantitatif, adalah data dalam bentuk angka yang dapat dinyatakan dan diukur dengan satuan hitung atau kualitatif yang diangkakan (Sugiyono, 2017:13). Angka yang dimaksud disini data jumlah populasi pelanggan produk fashion Discovery Shopping Mall Kuta dan skor jawaban kuesioner.

Teknik analisis jalur (Path Analisys) adalah teknik analisis data yang digunakan dalam penelitian ini. Analisis yang digunakan untuk menganalisis pola hubungan antar variabel untuk mengetahui adanya pengaruh langsung, pengaruh tidak langsung seperangkat variabel eksogen yang dalam penelitian ini adalah fashion involvement dan hedonic consumption tendency terhadap variabel endogen (emosi positif dan impulse buying) adalah analisis jalur (path analysis) yang dinyatakan oleh Riduwan dan Kuncoro (2011: 2) 


\section{HASIL DAN PEMBAHASAN}

Penelitian ini menggunakan 105 orang sebagai responden hal ini sesuai dengan ukuran sampel yang digunakan. Berdasarkan pada Tabel 1 data karakteristik responden, klarifikasi jenis kelamin peremuan mendominasi yakni sebesar 57,1 persen sedangkan persentase responden dengan jenis kelamin lakilaki yakni sebesar 42,9 persen. Hal ini berarti lebih banyaknya pelanggan wanita yang memiliki ketertarikan terhadap produk fashion di Discovery Shopping Mall Kuta dikarenakan produk fashion wanita cenderung lebih bervariasi dibandingkan produk fashion pria.

Tabel 1.

Karakteristik Responden

\begin{tabular}{|c|c|c|c|c|}
\hline No. & Variabel & Klasifikasi & $\begin{array}{l}\text { Jumah } \\
\text { (Orang) }\end{array}$ & $\begin{array}{l}\text { Persentase } \\
(\%)\end{array}$ \\
\hline \multirow{2}{*}{1} & \multirow{2}{*}{ Jenis Kelamin } & Laki-laki & 45 & 42,9 \\
\hline & & Perempuan & 60 & 57,1 \\
\hline \multicolumn{2}{|c|}{ Jumlah } & & 105 & 100 \\
\hline \multirow{6}{*}{2} & \multirow{6}{*}{ Usia } & $18-21$ & 59 & 56,2 \\
\hline & & $>21-26$ & 27 & 25,7 \\
\hline & & $>26-31$ & 4 & 3,8 \\
\hline & & $>31-36$ & 2 & 1,9 \\
\hline & & $>36-42$ & 5 & 4,8 \\
\hline & & Diatas 42 & 8 & 7,6 \\
\hline \multicolumn{2}{|c|}{ Jumlah } & & 105 & 100 \\
\hline \multirow{5}{*}{3} & \multirow{5}{*}{ Pekerjaan } & Pelajar/Mahasiswa & 66 & 62,8 \\
\hline & & Karyawan Swasta & 28 & 26,7 \\
\hline & & PNS/ABRI/TNI & 2 & 1,9 \\
\hline & & Pengusaha & 5 & 4,8 \\
\hline & & Lain-lain & 4 & 3,8 \\
\hline \multicolumn{2}{|c|}{ Jumlah } & & 105 & 100 \\
\hline \multirow{5}{*}{4} & \multirow{5}{*}{ Pendidikan Terakhir } & SMA/SMK & 64 & 61 \\
\hline & & Diploma & 6 & 5,7 \\
\hline & & $\mathrm{S} 1$ & 35 & 33,3 \\
\hline & & $\mathrm{S} 2$ & - & - \\
\hline & & S3 & - & - \\
\hline \multicolumn{2}{|c|}{ Jumlah } & & 105 & 100 \\
\hline
\end{tabular}

Sumber: Data Diolah, (2017) 
Selanjutnya bila dilihat dari usia responden mayoritas responden berusia 18-21 tahun yakni sebesar 56,2 persen, kemudian diikuti dengan kelompok usia >21- 26 tahun sebesar 25,7 persen, kelompok usia diatas 42 tahun sebesar 7,6 persen, diikuti kelompok usia >36-42 tahun sebesar 4,8 persen, selanjutnya kelompok usia >26-31 tahun sebesar 3,8 persen dan terakhir kelompok usia >3136 sebesar 1,9 persen. Klasifikasi selanjutnya yakni klasifikasi pekerjaan, yang dalam penelitian ini didominasi oleh klasifikasi Pelajar/Mahasiswa yakni sebesar 62,8 persen. Hal ini menunjukkan bahwa target utama dari Discovery Shopping Mall Kuta adalah pelajar/mahasiswa dikarenakan tingkat kejenuhan pelajar/mahasiswa tinggi sehingga membutuhkan tempat hiburan sekaligus rekreasi. Klasifikasi terakhir yakni klasifikasi pendidikan terakhir, yang dalam penelitian ini dibagi menjadi lima jenjang pendidikan diantaranya klasifikasi tingkat SMA/SMK yang mendominasi yakni sebesar 61 persen, kemudian klasifikasi S1 yakni sebesar 33.3 persen, dan yang terakhir klasifikasi Diploma sebesar 5,7 persen.

Tabel 2 menunjukkan hasil uji validitas instrument terhadap 21 indikator yang digunakan memiliki nilai korelasi lebih besar dari 0,3 sehingga keseluruhan indikator yang digunakan dinyatakan valid.

Tabel 3 hasil uji reliabilitas menunjukkan nilai cronbach's alpha masingmasing variabel diatas 0,60 hal ini berarti keseluruhan variabel dalam penelitian dinyatakan reliabel. 
Tabel 2.

Hasil Uji Validitas Instrumen

\begin{tabular}{|c|c|c|c|c|}
\hline No & Variabel & Indikator & $\begin{array}{c}\text { Koefisien } \\
\text { Korelasi }\end{array}$ & Keterangan \\
\hline \multirow{8}{*}{1} & \multirow{8}{*}{ Fashion involvement } & $\mathrm{X}_{1.1}$ & 0,785 & Valid \\
\hline & & $\mathrm{X}_{1.2}$ & 0,787 & Valid \\
\hline & & $\mathrm{X}_{1.3}$ & 0,858 & Valid \\
\hline & & $\mathrm{X}_{1.4}$ & 0,800 & Valid \\
\hline & & $\mathrm{X}_{1.5}$ & 0,935 & Valid \\
\hline & & $\mathrm{X}_{1.6}$ & 0,845 & Valid \\
\hline & & $\mathrm{X}_{1.7}$ & 0,775 & Valid \\
\hline & & $\mathrm{X}_{1.8}$ & 0,830 & Valid \\
\hline \multirow{3}{*}{2} & \multirow{3}{*}{ Hedonic consumption tendency } & $\mathrm{X}_{2.1}$ & 0,952 & Valid \\
\hline & & $\mathrm{X}_{2.2}$ & 0,936 & Valid \\
\hline & & $\mathrm{X}_{2.3}$ & 0,918 & Valid \\
\hline \multirow{4}{*}{3} & \multirow{4}{*}{ Emosi Positif } & $\mathrm{Y}_{1.1}$ & 0,835 & Valid \\
\hline & & $Y_{1.2}$ & 0,905 & Valid \\
\hline & & $\mathrm{Y}_{1.3}$ & 0,867 & Valid \\
\hline & & $Y_{1.4}$ & 0,864 & Valid \\
\hline \multirow{6}{*}{4} & \multirow{6}{*}{ Impulse buying } & $\mathrm{Y}_{2.1}$ & 0,804 & Valid \\
\hline & & $\mathrm{Y}_{2.2}$ & 0,886 & Valid \\
\hline & & $Y_{2.3}$ & 0,930 & Valid \\
\hline & & $Y_{2.4}$ & 0,840 & Valid \\
\hline & & $Y_{2.5}$ & 0,895 & Valid \\
\hline & & $Y_{2.6}$ & 0,933 & Valid \\
\hline
\end{tabular}

Sumber: Data Diolah, (2017)

Tabel 3.

Hasil Uji Reliabilitas Instrumen

\begin{tabular}{clcc}
\hline No & \multicolumn{1}{c}{ Variabel } & Cronbach's Alpha & Keterangan \\
\hline 1 & Fashion involvement & 0,931 & Reliabel \\
2 & Hedonic consumption tendency & 0,926 & Reliabel \\
3 & Emosi Positif & 0,890 & Reliabel \\
4 & Impulse buying & 0,936 & Reliabel \\
\hline
\end{tabular}

Sumber: Data Diolah, (2017)

Pengujian Kaiser Mayer Olkin dilakukan untuk mengetahui apakah variabel yang digunakan dalam penelitian saling berpengaruh.

Berdasarkan Tabel 4 dapat dilihat bahwa pada keseluruhan variabel memiliki nilai KMO diatas 0,05, nilai Chi Square keseluruhan variabel besar dengan tingkat signifikansi $\leq 0,05$ sehingga seluruh variabel dapat dinyatakan layak digunakan sebagai variabel dalam penelitian. 


\section{Tabel 4.}

Hasil Uji Kaiser Mayer Olkin dan Bartlett Test

\begin{tabular}{clccc}
\hline No & \multicolumn{1}{c}{ Variabel } & $\begin{array}{c}\text { Kaiser Mayer } \\
\text { Olkin }\end{array}$ & $\boldsymbol{X}^{2}$ Chi Square & Significance Probability \\
\hline 1 & Fashion involvement & 0,918 & 550,226 & 0,000 \\
2 & Hedonic consumption & 0,725 & 129,247 & 0,000 \\
3 & tendency & 0,827 & 185,903 & 0,000 \\
4 & Emosi Positif & 0,870 & 323,228 & 0,000 \\
\hline
\end{tabular}

Sumber: Data Diolah, (2017)

Tabel 5.

Hasil Eigen Value

\begin{tabular}{clc}
\hline No & Variabel & Eigen Value \\
\hline 1 & Fashion involvement & 5,231 \\
2 & Hedonic consumption tendency & 2,293 \\
3 & Emosi Positif & 2,841 \\
4 & Impulse buying & 3,901 \\
\hline
\end{tabular}

Sumber: Data Diolah, (2017)

Tabel 5 diatas menunjukkan keseluruhan variabel dalam penelitian memiliki nilai $>1,00$, hal ini menunjukkan variabel fashion involvement, hedonic consumption tendency, emosi positif, dan impulse buying sudah memenuhi syarat sebagai variabel dalam melakukan penelitian.

Tabel 6 .

Hasil Cummulative Variance

\begin{tabular}{clc}
\hline No & \multicolumn{1}{c}{ Variabel } & $\begin{array}{c}\text { Cummulative } \\
\text { Variance }\end{array}$ \\
\hline 1 & Fashion involvement & 65,386 \\
2 & Hedonic consumption tendency & 76,444 \\
3 & Emosi Positif & 71,027 \\
4 & Impulse buying & 65,019 \\
\hline
\end{tabular}

Sumber: Data Diolah, (2017)

Berdasarkan Tabel 6 dapat dilihat variabel fashion involvement memiliki nilai cumulative variance 65,386 variabel hedonic consumption tendency memiliki nilai cumulative variance 76,444 emosi positif memiliki nilai cumulative variance 71,027 dan impulse buying memiliki nilai cumulative 
Ida Ayu Diksita Kinasih, Peran Emosi Positif Memediasi...

variance 65,019, maka dapat ditarik kesimpulan bahwa variabel fashion involvement, hedonic consumption tendency, emosi positif, impulse buying mampu dijadikan sebagai variabel penelitian karena telah memenuhi persyaratan.

Indikator dalam penelitian dinyatakan layak digunakan apabila memiliki nilai loading factor sudah $>0,5$. Tabel 7 menunjukkan hasil olah data terkait Loading Factor.

Tabel 7.

Hasil Loading Factor

\begin{tabular}{|c|c|c|c|}
\hline No & Variabel & Indikator & Loading Factor \\
\hline \multirow[t]{8}{*}{1} & Fashion involvement & $\mathrm{X}_{1.1}$ & 0,813 \\
\hline & & $\mathrm{X}_{1.2}$ & 0,859 \\
\hline & & $\mathrm{X}_{1.3}$ & 0,836 \\
\hline & & $\mathrm{X}_{1.4}$ & 0,708 \\
\hline & & $\mathrm{X}_{1.5}$ & 0,851 \\
\hline & & $\mathrm{X}_{1.6}$ & 0,870 \\
\hline & & $\mathrm{X}_{1.7}$ & 0,713 \\
\hline & & $\mathrm{X}_{1.8}$ & 0,801 \\
\hline \multirow[t]{3}{*}{2} & Hedonic consumption tendency & $\mathrm{X}_{2.1}$ & 0,879 \\
\hline & & $\mathrm{X}_{2.2}$ & 0,888 \\
\hline & & $\mathrm{X}_{2.3}$ & 0,856 \\
\hline \multirow[t]{4}{*}{3} & Emosi Positif & $\mathrm{Y}_{1.1}$ & 0,830 \\
\hline & & $\mathrm{Y}_{1.2}$ & 0,865 \\
\hline & & $\mathrm{Y}_{1.3}$ & 0,835 \\
\hline & & $\mathrm{Y}_{1.4}$ & 0,842 \\
\hline \multirow[t]{6}{*}{4} & Impulse buying & $\mathrm{Y}_{2.1}$ & 0,814 \\
\hline & & $\mathrm{Y}_{2.2}$ & 0,843 \\
\hline & & $\mathrm{Y}_{2.3}$ & 0,811 \\
\hline & & $\mathrm{Y}_{2.4}$ & 0,800 \\
\hline & & $\mathrm{Y}_{2.5}$ & 0,806 \\
\hline & & $\mathrm{Y}_{2.6}$ & 0,761 \\
\hline
\end{tabular}

Sumber: Data Diolah, (2017)

Tabel 7 menunjukkan loading factor dari masing-masing variabel fashion involvement, hedonic consumption tendency, emosi positif, dan impulse buying 
semuanya sudah > 0,5 yang memiliki arti keseluruhan indikator-indikator penelitian dinyatakan valid sebagai sebuah variabel yang akan diteliti.

Untuk mengetahui apakah model regresi yang dibuat memiliki distribusi normal atau tidak maka dapat dilakukan dengan uji normalitas.

Tabel 8.

Hasil Uji Normalitas Persamaan Regresi 1

\begin{tabular}{cc}
\hline & Unstandardized Residual \\
\hline $\mathrm{N}$ & 105 \\
Kolmogorov-Smirnov & 0,755 \\
Asymp.Sig. (2-tailed) & 0,619 \\
\hline
\end{tabular}

Sumber: Data Diolah, (2017)

Tabel 8 menunjukkan nilai Kolmogorov Smirnov $(K-S)$ dan nilai Asymp. Sig. (2-tailed) masing - masing bernilai 0,755 dan 0,619. Berdasarkan hasil menunjukkan bahwa nilai Asymp. Sig. (2-tailed) 0,619 lebih besar daripada nilai alpha 0,05 , maka dapat dinyatakan bahwa model persamaan regresi berdistribusi normal.

Tabel 9.

Hasil Uji Normalitas Persamaan Regresi 2

\begin{tabular}{cc}
\hline & Unstandardized Residual \\
\hline $\mathrm{N}$ & 105 \\
Kolmogorov-Smirnov & 0,798 \\
Asymp.Sig. (2-tailed) & 0,548 \\
\hline
\end{tabular}

Sumber: Data Diolah, (2017)

Tabel 9 menunjukkan nilai Kolmogorov Smirnov (K-S) dan Asymp. Sig. (2-tailed) masing - masing sebesar 0,798 dam 0,548. Maka berdasarkan hasil 
tersebut nilai Asymp.Sig. (2-tailed) sebesat 0,548 dan nilai lebih besar dari nilai alpha 0,05 , seingga model persamaan regresi dinyatakan berdistribusi normal.

Adanya multikoliniearitas dapat dilihat dari nilai tolerance atau variance inflaction factor (VIF).

Tabel 10.

Hasil Uji Multikoliniearitas Persamaan Regresi 1

\begin{tabular}{lcc}
\hline \multicolumn{1}{c}{ Variabel } & Tolerance & VIF \\
\hline Fashion involvement & 0,394 & 2,535 \\
Hedonic consumption tendency & 0,394 & 2,535 \\
\hline
\end{tabular}

Sumber: Data Diolah, (2017)

Tabel 10 menunjukkan bahwa nilai tolerance untuk setiap variabel lebih besar dari $10 \%$ dan nilai VIF lebih kecil dari 10 yang berarti model persaman regresi 1 bebas dari multikoliniearitas.

Tabel 11.

Hasil Uji Multikoliniearitas Persamaan Regresi 2

\begin{tabular}{lcc}
\hline \multicolumn{1}{c}{ Variabel } & Tolerance & VIF \\
\hline Fashion involvement & 0,331 & 3,026 \\
Hedonic consumption tendency & 0,349 & 2,863 \\
Emosi Positif & 0,409 & 2,444 \\
\hline
\end{tabular}

Sumber: Data Diolah, (2017)

Berdasarkan Tabel 11 Dapat dilihat nilai tolerance dan VIF dari variabel fashion involvement, hedonic consumption tendency, dan emosi positif. Nilai pada tabel menunjukkan bahwa nilai tolerance untuk setiap variabel lebih besar dari $10 \%$ dan nilai VIF lebih kecil dari 10 yang berarti model persamaan regresi 2 bebas dari multikoliniearitas. 
Untuk mengetahui terjadinya ketidaksamaan variabel dan residual terhadap pengamatan lainnya dapat dilakukan dengan uji heterokedaastisitas dengan menjalankan metode uji Glejser.

Tabel 12.

Hasil Uji Heteroskedastisitas Persamaan Regresi 1

\begin{tabular}{|c|c|c|c|c|c|}
\hline \multirow[t]{2}{*}{ Model } & \multicolumn{2}{|c|}{$\begin{array}{c}\text { Unstandardized } \\
\text { Coefficients }\end{array}$} & \multirow{2}{*}{$\begin{array}{c}\begin{array}{c}\text { Standardized } \\
\text { Coefficients }\end{array} \\
\text { Beta } \\
\end{array}$} & \multirow[t]{2}{*}{$\mathbf{t}$} & \multirow[t]{2}{*}{ Sig. } \\
\hline & B & Std. Error & & & \\
\hline $1 \quad$ (Constant) & 1,087 & 0,634 & & 1,714 & 0,090 \\
\hline Fashion involvement & 0,014 & 0,030 & 0,076 & 0,480 & 0,633 \\
\hline $\begin{array}{l}\text { Hedonic Consumption } \\
\text { Tendency }\end{array}$ & $-0,031$ & 0,079 & $-0,063$ & 0,400 & 0,690 \\
\hline
\end{tabular}
Sumber: Data Diolah, (2017)

Pada tabel 12 dapat dilihat bahwa nilai signifikansi dari variabel fashion involvement sebesar 0,633 lebih besar dari 0,05 dan begitu pula dengan hedonic consumption tendency 0,690 yang lebih besar dari 0,05. Hal ini berarti bahwa variabel bebas tidak berpengaruh terhadap absolute residual. Maka, tidak terdapat gejala heteroskedastisitas pada model yang digunakan.

Tabel 13.

Hasil Uji Heteroskedastisitas Persamaan Regresi 2

\begin{tabular}{llccccc}
\hline \multirow{2}{*}{ Model } & \multicolumn{2}{c}{$\begin{array}{c}\text { Unstandardized } \\
\text { Coefficients }\end{array}$} & $\begin{array}{c}\text { Standardized } \\
\text { Coefficients }\end{array}$ & t & \multirow{2}{*}{ Sig. } \\
\cline { 3 - 5 } & B & Std. Error & Beta & & \\
\hline 1 & (Constant) & 2,757 & 1,024 & & 2,647 & 0,009 \\
& Fashion involvement & 0,053 & 0,050 & 0,181 & 1,059 & 0,292 \\
& Hedonic Consumption & $-0,024$ & 0,127 & $-0,032$ & $-0,192$ & 0,848 \\
Tendency & & & & & \\
Emosi Positif & $-0,138$ & 0,101 & $-0,211$ & $-1,375$ & 0,172 \\
\hline \multicolumn{2}{l}{ a. Dependent Variable: Absres2 } & & & & \\
\hline
\end{tabular}

Sumber: Data Diolah, (2017)

Pada Tabel 13 dapat dilihat bahwa nilai signifikansi dari variabel fashion involvement, hedonic consumption tendency, dan emosi positif masing-masing 
sebesar 0,$292 ; 0,848 ; 0,172$. Nilai tersebut lebih besar daripada 0,05 menunjukkan bahwa antara variabel bebas tidak berpengaruh terhadap absolute residual. Dengan demikian, tidak terdapat gejala heteroskedastisitas dalam model regresi yang dirancang.

Teknik analisis yang digunakan dalam melakukan penelitian ini adalah teknik analisis jalur (Path Analysis). Analisis jalur merupakan sebuah teknik analisis yang lebih luas dari analisis regresi linear berganda yang digunakan untuk mengetahui hubungan kausalitas antara 2 atau lebih variabel. Untuk mengetahui koefisien path dalam penelitian ini dilakukan melalui Software SPSS 17.0 for Windows, dan diperoleh hasil yang ditunjukkan pada Tabel 5.

Tabel 14.

Hasil Analisis Jalur Persamaan Regresi 1

\begin{tabular}{|c|c|c|c|c|c|}
\hline \multirow[t]{2}{*}{ Model } & \multicolumn{2}{|c|}{$\begin{array}{c}\text { Unstandardized } \\
\text { Coefficients }\end{array}$} & \multirow{2}{*}{$\begin{array}{c}\begin{array}{c}\text { Standardized } \\
\text { Coefficients }\end{array} \\
\text { Beta } \\
\end{array}$} & \multirow[t]{2}{*}{$\mathbf{T}$} & \multirow[t]{2}{*}{ Sig. } \\
\hline & $\mathbf{B}$ & Std. Error & & & \\
\hline 1 (Constant) & 3,934 & 0,949 & & 4,144 & 0,000 \\
\hline Fashion involvement & 0,201 & 0,045 & 0,448 & 4,444 & 0,000 \\
\hline $\begin{array}{l}\text { Hedonic Consumption } \\
\text { Tendency }\end{array}$ & 0,428 & 0,118 & 0,367 & 3,636 & 0,000 \\
\hline
\end{tabular}

Sumber: Data Diolah, (2017)

Tabel 14 menunjukkan hasil analisis jalur pada substruktur 1, adapun persamaan strukturalnya adalah sebagai berikut:

$$
\begin{aligned}
& Y_{1}: \beta_{1} X_{1}+\beta_{2} X_{2}+\varepsilon_{1} \\
& Y_{1}: 0,448 X+0,367 X+\varepsilon_{1}
\end{aligned}
$$


Tabel 15.

Hasil Analisis Jalur Persamaan Regresi 2

\begin{tabular}{|c|c|c|c|c|c|}
\hline \multirow[t]{2}{*}{ Model } & \multicolumn{2}{|c|}{$\begin{array}{c}\text { Unstandardized } \\
\text { Coefficients }\end{array}$} & \multirow{2}{*}{$\begin{array}{c}\begin{array}{c}\text { Standardized } \\
\text { Coefficients }\end{array} \\
\text { Beta } \\
\end{array}$} & \multirow[t]{2}{*}{$\mathbf{T}$} & \multirow[t]{2}{*}{ Sig. } \\
\hline & B & Std. Error & & & \\
\hline $\begin{array}{ll}1 & \text { (Constant) }\end{array}$ & $-6,328$ & 1,697 & & $-3,728$ & 0,000 \\
\hline Fashion involvement & 0,272 & 0,082 & 0,295 & 3,332 & 0,001 \\
\hline $\begin{array}{l}\text { Hedonic Consumption } \\
\text { Tendency }\end{array}$ & 0,503 & 0,207 & 0,209 & 2,432 & 0,017 \\
\hline Emosi Positif & 0,900 & 0,164 & 0,437 & 5,493 & 0,000 \\
\hline $\mathrm{R}_{1}^{2}: 0,738$ & $: 94,968$ & & $: 0,000$ & & \\
\hline
\end{tabular}

Sumber: Data Diolah, (2017)

Berdasarkan hasil analisis jalur substruktur 2 seperti yang disajikan pada tabel 15 maka persamaan strukturalnya adalah sebagai berikut:

$$
\begin{aligned}
& Y_{2}: \beta_{3} X_{1}+\beta_{4} X_{2}+\beta_{5} Y_{1}+\varepsilon_{2} \\
& Y_{2}: 0,295 X+0,209 X+0,437 Y_{1}+\varepsilon 2
\end{aligned}
$$

Sebelum menyusun diagram jalur akhir, terlebih dahulu dihitung nilai standar error sebagai berikut:

$$
\begin{aligned}
& \mathrm{e}=\sqrt{1-\mathrm{R} 1}^{2} \\
& \mathrm{e}_{1}=\sqrt{1-R 1}^{2}=\sqrt{1-0,591}=0,639 \\
& \mathrm{e}_{2}=\sqrt{1-R 2}^{2}=\sqrt{1-0,738}=0,511
\end{aligned}
$$

Berdasarkan perhitungan pengaruh error (e), didapatkan hasil pengaruh error $\left(e_{1}\right)$ sebesar 0,639 dan pengaruh error $\left(e_{2}\right)$ sebesar 0,511. Hasil koefisien determinasi total adalah sebagai berikut:

$$
\begin{aligned}
\mathrm{R}^{2}{ }_{\mathrm{m}} & =1-\left(\mathrm{Pe}_{1}\right)^{2}\left(\mathrm{Pe}_{2}\right)^{2} \\
& =1-(0,639)^{2}(0,511)^{2} \\
& =1-(0,408)(0,261) \\
& =1-0,106=0,894
\end{aligned}
$$

Nilai determinasi total sebesar 0,894 mempunyai arti bahwa sebesar 89,4 persen variasi impulse buying dipengaruhi oleh fashion involvement, hedonic consumption tendency dan emosi positif sedangkan sisanya sebesar 10,6 persen dijelaskan oleh faktor lain yang tidak dimasukkan ke dalam model. 
Berdasarkan hasil pengujian hipotesis pengaruh fashion involvement terhadap emosi positif diperoleh nilai koefisien Beta sebesar 0,448 dengan tingkat signifikansi sebesar $0,000(\leq 0,05)$ yang berarti $\mathrm{H}_{0}$ ditolak dan $\mathrm{H}_{1}$ diterima. Hal ini menunjukkan variabel fashion involvement berpengaruh positif dan signifikan terhadap emosi positif. Hal ini berarti bahwa semakin baik keterlibatan terhadap produk fashion yang dialami pelanggan maka akan semakin meningkatkan emosi positif ketika sedang berbelanja produk fashion di Discovery Shopping Mall Kuta. Hasil penelitian ini sesuai dengan hasil penelitian beberapa penelitian yang telah dilakukan sebelumnya oleh Amiri et al. (2012) sejalan dengan hasil penelitian Park et al. (2006) menunjukkan bahwa fashion involvement berpengaruh secara positif terhadap emosi positif dalam waktu pembelian. Hasil penelitian ini juga didukung dengan hasil penelitian Willy \& Warmika (2015) dan Pattipeilohy et al. (2013) yang mengungkapkan hasil yang sama bahwa fashion involvement berpengaruh positif dan signifikan terhadap impulse buying.

Berdasarkan hasil pengujian hipotesis pengaruh hedonic consumption tendency terhadap emosi positif diperoleh nilai koefisien Beta sebesar 0,367 dengan tingkat signifikansi sebesar $0,000(\leq 0,05)$ yang berarti $\mathrm{H}_{0}$ ditolak dan $\mathrm{H}_{1}$ diterima. Hasil ini dapat diartikan variabel hedonic consumption tendency berpengaruh positif dan signifikan terhadap emosi positif. Hal ini berarti bahwa semakin baik kecenderungan konsumsi hedonis pelanggan maka akan semakin meningkatkan emosi positif pelanggan produk fashion di Discovery Shopping Mall Kuta. Hasil penelitian ini sesuai dengan hasil beberapa penelitian yang 
telah dilakukan sebelumnya oleh Park et al. (2006), Permatasari dkk. (2017), Marianty (2014) dan Riana dkk. (2015) yang juga mengungkapkan hasil yang sama bahwa hedonic consumption tendency berpengaruh positif dan signifikan terhadap emosi positif.

Berdasarkan hasil pengujian hipotesis pengaruh fashion involvement terhadap impulse buying diperoleh nilai koefisien Beta sebesar 0,295 dengan tingkat signifikansi sebesar $0,001(\leq 0,05)$ yang berarti $\mathrm{H}_{0}$ ditolak dan $\mathrm{H}_{1}$ diterima. Hasil ini menunjukkan variabel fashion involvement berpengaruh positif dan signifikan terhadap impulse buying. Hal ini berarti semakin baik fashion involvement maka akan semakin meningkatkan impulse buying pelanggan produk fashion Discovery Shopping Mall Kuta. Hasil penelitian ini sesuai dengan hasil dari beberapa penelitian yang telah dilakukan sebelumnya oleh Amiri (2012) dan Vazfehdoost (2014) menghasilkan bahwa fashion involvement berpengaruh positif terhadap impulse buying. Penelitiaan yang dilakukan oleh Willy \& Warmika (2015) dan Dananjaya \& Suparna (2016) menghasilkan temuan bahwa fashion involvement berpengaruh positif dan signifikan terhadap impulse buying juga mendukung temuan penelitian ini.

Berdasarkan hasil pengujian hipotesis pengaruh hedonic consumption tendency terhadap impulse buying diperoleh nilai koefisien Beta sebesar 0,209 dengan tingkat signifikansi sebesar $0,017(\leq 0,05)$ yang berarti $\mathrm{H}_{0}$ ditolak dan $\mathrm{H}_{1}$ diterima. Hasil tersebut berarti bahwa variabel hedonic consumption tendency berpengaruh positif dan signifikan terhadap impulse buying. Hal ini berarti semakin baik hedonic consumption tendency maka akan semakin meningkat pula 
impulse buying pelanggan produk fashion ketika berada di Discovery Shopping Mall Kuta. Hasil penelitian ini sesuai dengan hasil dari beberapa penelitian yang telah dilakukan sebelumnya oleh Permatasari dkk. (2017) yakni hedonic consumption tendency berpengaruh secara signifikan terhadap impulse buying. Hasil penelitian Marianty (2014) dan Riana dkk. (2015) juga mendukung hasil penelitian ini yakni hedonic consumption tendency berpengaruh positif dan signifikan terhadap impulse buying.

Berdasarkan hasil pengujian hipotesis pengaruh emosi positif terhadap impulse buying memperoleh hasil nilai koefisien Beta sebesar 0,437 dengan tingkat signifikansi sebesar $0,000(\leq 0,05)$ yang berarti $\mathrm{H}_{0}$ ditolak dan $\mathrm{H}_{1}$ diterima. Hasil tersebut berarti bahwa variabel emosi positif berpengaruh positif dan signifikan terhadap impulse buying. Hal ini berarti bahwa semakin tinggi emosi positif maka semakin meningkat pula impulse buying pelanggan produk fashion Discovery Shopping Mall Kuta. Hasil penelitian ini sesuai dengan hasil dari beberapa penelitian yang telah dilakukan sebelumnya oleh Amiri (2012) dan Naentiana \& Setiawan (2014) yang menyatajan bahwa emosi positif berpengaruh positif terhadap impulse buying. Permatasari dkk. (2017) dalam penelitiannya yang juga mengungkapkan hasil yang sama bahwa emosi positif berpengaruh positif dan signifikan terhadap impulse buying.

Untuk menguji signifikansi hubungan tidak langsung antara variabel independen dengan variabel dependen yang dimediasi oleh variabel mediator digunakan Uji Sobel. Variabel mediasi dinilai signifikan memediasi hubungan 
antara variabel terikat dan variabel bebas apabila memiliki nilai $\mathrm{Z}$ lebih besar 1,96 dengan tingkat kepercayaan 95 persen.

Peran Emosi Positif Memediasi Fashion involvement terhadap Impulse buying

$$
\begin{aligned}
& Z=\frac{0,448086.0,437135}{\sqrt{0,448086^{2} 0,163775^{2}+0,437135^{2} 0,045149^{2}+0,045149^{2} 0,163775^{2}}} \\
& Z=\mathbf{2 . 5 6 5 4}
\end{aligned}
$$

Hasil pengujian uji sobel pada penelitian ini menunjukkan hasil tabulasi $\mathrm{Z}=2,5654$ yang lebih besar daripada 1,96 dengan tingkat signifikansi 0,0103 yang lebih kecil dari 0,05 yang berarti Emosi Positif sebagai variabel mediasi dinilai secara signifikan mampu memediasi pengaruh fashion involvement terhadap impulse buying.

Pernyataan ini sejalan dengan hasil penelitian yang dilakukan oleh Beatty, Ferrell dan Sherma et al, (dalam Park et al. 2006) menghasilkam bahwa emosi positif saat berblanja dapat menjadi mediator yang signifikan dalam mendorong impulse buying. Hal serupa juga diungkapkan Willy \& Warmika (2015) dalam penelitiannya yang menghasilkan bahwa secara signifikan emosi positif mampu memediasi pengaruh fashion involvement terhadap impulse buying.

Peran Emosi Positif Memediasi Hedonic Consumption Tendency terhadap Impulse buying

$$
\begin{aligned}
& Z=\frac{0,36663.0,437135}{\sqrt{0,36663^{2} 0,163775^{2}+0,437135^{2} 0,11761^{2}+0,11761^{2} 0,163775^{2}}} \\
& Z=\mathbf{1 , 9 6 9 8}
\end{aligned}
$$


Hasil pengujian uji sobel pada penelitian ini menunjukkan hasil tabulasi $\mathrm{Z}=1,9698$ yang lebih besar daripada 1,96 dengan tingkat signifikansi 0,0489 yang lebih kecil dari 0,05 yang berarti Emosi Positif sebagai variabel mediasi dinilai secara signifikan mampu memediasi pengaruh Hedonic consumption tendency terhadap Impulse buying.

Hal ini didukung oleh beberapa peneltian sebelumnya yang dilakukan oleh Permatasari dkk. (2017), dan Riana dkk. (2015), Park et al. (2006) yang menghasilkan bahwa emosi positif merupakan variabel mediasi yang signifikan antara hedonic consumption tendency terhadap impulse buying.

\section{SIMPULAN DAN SARAN}

Perilaku pembelian impulsif pada pelanggan produk fashion Discovery Shopping Mall Kuta secara umum dipengaruhi oleh variabel fashion involvement, hedonic consumption tendency dan emosi positif secara positif dan signifikan. Variabel emosi positif dapat berperan sebagai variabel mediasi pengaruh fashion involvement dan hedonic consumption tendency terhadap impulse buying.

Berdasarkan hasil pembahasan dan simpulan, maka saran yang dapat diberikan adalah sebagai berikut. Mengingat indikator "Lebih mengetahui adanya fashion terbaru dibandingkan dengan orang lain" merupakan indikator terendah dari variabel fashion involvement, maka sebaiknya Discovery Shopping Mall Kuta meningkatkan promosi pengenalan koleksi produk fashion ter up-date yang dimiliki melalui website Discovery Shopping Mall Kuta ataupun brosur. 
Indikator "Ingin merasa seperti sedang menjelajahi dunia baru saat sedang berada di pusat perbelanjaan" merupakan indikator terendah dari variabel hedonic consumption tendency, maka sebaiknya Discovery Shopping Mall Kuta mampu menjadi tempat berbelanja produk fashion yang sesuai kebutuhan pelanggan yang selalu mengikuti jaman dengan menjual produk fashion terbaru sehingga pelanggan akan merasa seperti sedang menjelajahi dunia baru saat sedang berada di Discovery Shopping Mall Kuta. Mengingat indikator "Penuh dengan emosi positif" merupakan indikator terendah dari variabel emosi positif maka sebaiknya, pihak Discovery Shopping Mall Kuta meningkatkan kenyamanan dan keamanan lingkungan serta kualitas layanan di sekitar mall agar dapat menimbulkan emosi positif pelanggan ketika sedang berbelanja di Discovery Shopping Mall Kuta. Indikator "Cenderung membeli produk fashion meskipun tidak begitu membutuhkannya" merupakan indikator terendah dari variabel impulse buying, maka sebaiknya meningkatkan tampilan gerai fashion semenarik mungkin sehingga pelanggan terdorong untuk melakukan pembelian secara impulsif.

\section{REFERENSI}

Amiri, Farhad; Jalal Jasour; Mohsen Shirpur; Tohid Alizzadeh. 2012. Evaluation of Effective Fashionism Involvment Factors Effects on Impulse buying of Customer and Condition of Interrelation Between These Factors. Journal of Basic and Applied Scientific Research, 2 (9), 9413-9419.

Beatty, Sharon E. and M. Elizabeth Ferrel. 1998. Impulse buying: Modeling its Precursor. Journal of Retailing, 74 (2). 169-191. 
Chaudhuri, A; Holbrook, M.B. 2002. "Product-Class Effects on Brand Commitment and Brand Outcomes: The Role of Brand Trust and Brand Effect", Journal of Brand Management, 10 (1); ABI/INFORM Global, 3358.

Dananjaya, I Gde Made Ray Anom dan Gede Suparna. 2016. Hedonic consumption tendency Dan Impulse buying Pelanggan Produk Fashion di Mall Bali Galeria. E-Jurnal Manajemen Unud, 5 (4), 2250-2282.

Dhurup, Maniall (Prof). 2014. Impulsive Fashion Apparel Consumption: The Role of Hedonism, Fashion involvement and Emotional Gratification in Fashion Apparel Impulsive Buying Behaviour in a Developing Country. Mediterranean Journal of Social Sciences, 5 (8) 168-177.

Guitierrez, Ben Paul B. 2004. Determinats of Planned and Impulse Buying: The Case of The Phillippines. Asia Pasific Management Review, 9 (6) 10611078 .

Hausman, A. 2000. A Multi-Method Investigation Of Consumer Motivations In Impulse buying Behavior. Journal of Consumer Marketing, 17 (5), 403-19.

Hoch, S. J., \& Loewenstein, G. F. 1991. Time-inconsistent preferences and consumer self-control. Journal of Consumer Research, 17 (4), 492-507.

Hourigan, Sally Rebecca \& Ursula Sigrid Bougoure. 2012. Toward a Better Understanding of Fashion Clothing Involvement. Australian Marketing Journal, 20 (2), 127-135.

Japarianto, Edwin dan Sugiharto, Sugiono. 2011. Pengaruh Shopping Life Style Dan Fashion involvement terhadap Impulse buying Behavior Masyarakat High Income Surabaya. Jurnal Manajemen Pemasaran, 6 (1), 32-41.

Japarianto, Edwin dan Lizamary Angelina Darma. 2014. Analisa Pengaruh Hedonic Shopping Value Terhadap Impulse buying Dengan Shopping Lifestyle Dan Positive Emotion Sebagai Variabel Intervening Pada Mall Ciputra World Surabaya. Jurnal Manajemen Pemasaran, 8 (2), 80-89.

Khare, Arpita \& Sapna Rakesh. 2010. Predictor of Fashion Clothing Involvement Among Indian Youth. Journal of Targeting, Mesurement and Analysis for Marketing, 18 (3), 209-220.

Liapati, Giorgia; Ioannis Assiouras \& Jean-Marc Decaudin. 2015. The role of fashion involvement, brand love and hedonic consumption tendency in fashion impulse purchasing. Journal of Global Fashion Marketing Bridging Fashion and Marketing, 6 (4), 251-264. 
Marianty, R. 2014. Pengaruh Keterlibatan Fashion, Emosi Positif, dan Kecenderungan Konsumsi Hedonik Terhadap Pembelian Impulsif. Pasca Sarjana Universitas Atma Jaya Yogyakarta, 1-15.

Mulyono, Fransisca. 2012. Faktor Demografis Dalam Perilaku Pembelian Impulsif. Jurnal Administrasi Bisnis, 8 (1), 88-105.

Muruganantham, G dan Ravi Shankar Bhakat. 2013. A Review of Impulse buying Behaviour. International Journal of Marketing Studies, 5 (3), 149-160.

Naentiana,Putu Vera; Putu Yudi Setiawan. 2014. Skripsi: Peran Positive Emotion dalam Memediasi Pengaruh Hedonic Shopping Value Terhadap Impulse buying (Studi Kasus: Mall Bali Galeria). Fakultas Ekonomi dan Bisnis Universitas Udayana.

Nooreini, Abdolmajid. 2014. The Role Of Fashion Orientated Involvement And Individual Mood On Impulse buying In Tabriz. Arabian Journal of Business and Management Review (OMAN Chapter), 3 (12), 132-138.

O'Cass, Aron. 2004. Fashion Clothing Consumption: Antecedents and Conseques of Fashion Clothing Involvement. European Journal of Marketing, 7 (38), 869.

Park, Eun Joo, Eun Young Kim dan Judith Cardona Forney. 2006. A Structural Model of Fashion-Oriented Impulse buying Behavior. Journal of Fashion Marketing and Management, 10 (4), 433-446.

Permatasari, Intan Mazidah;Zainul Arifin \&Sunarti. 2017. Pengaruh Hedonic Consumption Dan Mediator Emosi Positif Terhadap Pembelian Impulsif. Jurnal Administrasi Bisnis (JAB), 43 (2), 1-9.

Prihastama, Brian Vicky. 2016. Skripsi: Pengaruh Price Discount Dan Bonus Pack Terhadap Impulse buying Pada Pelanggan Minimarket (Studi Pada Pelanggan Minimarket Indomaret Jl. Demangan Baru, Depok, Sleman, Yogyakarta). Program Studi Manajemen. Universitas Negeri Yogyakarta.

Rachmawati, Veronica. 2009. Hubungan antara Hedonic Shopping Value, Positive Emotion, dan Perilaku Impulse buying pada Konsumen Ritel. Majalah Ekonomi, 19 (2), 192-209.

Riana Dewi, Novi; Suharyono, Srikandi Kumadji. 2015. Pengaruh Fashion Involvemet Dan Kecenderungan Hedonic Consumption Dengan Mediator Emosi Positif Terhadap Pembelian Impulsif Berorientasi Fashion. Jurnal Administrasi Bisnis (JAB), 26 (2), 1-10. 
Rohman, Fatchur. 2012. Peran Faktor Situasional dan Perilaku Pembelian Impulsif. Malang: Tim UB Press.

Saleem, Muhammad. H., Rao A,A. and Saeed A. 2012. Post Purchase Cognitive Dissonance: Impact of Product Involvement, Impulse buying and Hedonic Consumption Tendencies. Interdiclipinary Journal of Contenporary Research in Business, 4 (5), 1052-1060.

Sugiyono. 2017. Metode Penelitian Bisnis. Bandung: Alfabeta.

Vazifehdoost, Hossein, Afshin Rahnama \& Sayed Javed Mousavian. 2014. Evaluation of the Influence of Fashion involvement, Personality Characteristics, Tendency to Hedonic Consumption and Store Environment on Fashion-Oriented Impulse buying. Mediterranean Journal of Social Sciences, 5 (16), 224-231.

Willy Setiadi, I Made dan I Gde Ketut Warmika. 2015. Pengaruh Fashion involvement Terhadap Impulse buying Konsumen Fashion Yang Dimediasi Positive Emotion Di Kota Denpasar. E-Jurnal Manajemen Unud, 4 (6), 1684-1700. 